\title{
Preface: Reflections on Reflexivity
}

This book is about the production and consumption of history. Much of it is framed by the concerns with which my generation (I was born in 1972) had the honour to come of age professionally, and which will probably be remembered as the age of the posts, affectionately known now as postmodernism and postcolonialism. Several parallel themes crosscut the book's central focus on the discipline of history: its intellectual history, its historiography and its connection to memory, particularly in relation to the need to establish the collective identity of "nation", "community" or state through a memorialisation process that has much to do with history, or at least with claiming a historicity for collective memory. None of this can be undertaken without an understanding of the roles that history writing and history reading have played in public debates, or perhaps more accurately in public disputes.

If this book seems to some to be obsolete at its moment of publication, this also illustrates the cyclical nature of apparently linear time: we are spiralling downwards along the same vortex as our historical predecessors. "History" must serve certain instrumental purposes, and if it does not, various people, self-appointed guardians of "interests" and "sentiments", reserve the right to get upset. No one questions this right; it is as if the domain of the historian is to provide serviceable histories to diverse people at the expense of an earlier (albeit inflated and arrogant) claim to "accuracy". Has this trend now intensified? Are human beings getting more and more hypersensitive about perceived affronts to their collective identities? Or is history being increasingly called upon to provide a "safe space" in which no one is to be offended without a trigger warning being provided first, shadowing, as it were, classroom practices in North American universities? The past has never been that safe space; but history is not entirely about the past, the past is not all history, nor, as someone might have noticed, is the present a safe space. Then again, the safe space argument is about creating such non-threatening spaces as special zones. Should these special zones be confused with the larger world? Should historians have a role in the creation of such spaces in historical narrative?

In keeping with my formative experiences as a "South Asianist", a good deal of the material presented here is specific to that area studies framework, but its resonances across the discipline of history should, I think, be apparent. A set of observations emerges from this material: firstly, that histories of "India" (and histories of the "Global South", the "Third World" or whatever collective shorthand one claims to historically stand for less privileged spaces) have come to rely inordinately on victimhood narratives for legitimation (and "victimhood" 
at a national level seems to be a strange claim to make, especially for a country that purports at the same time to be an economic giant and a major political player on the world stage). Secondly, the collective memory that is sought to be legitimised as history is nation-state-centric; this often closes off other forms of collective memory, or creates ambivalences and tensions among the national and divergent regional, anti- or non-national collective memories. Since the "nation" is itself a legitimator for the state, the state appropriates and instrumentalises the victimhood narratives of its "nation"(s). Thirdly, there appear to be moral positions to defend rather than research questions to answer; concurrently, an apparent collective retreat from the archives leaves historians without a basis for many of their arguments in the discipline of history itself. Fourthly, as histories are increasingly called upon to perform various public functions such as to legitimate collective claims to identity, it is a history-consuming public that gets to set a large part of the agenda for the public life of historiography, and we must ask as a matter of urgency to what extent and how professional historians should respond to these claims. Fifthly (and this probably applies across the humanities and social sciences), there has been a deterioration of professional standards and an anointing of mediocrity and conformity as principles to which to adhere in academic life, where institutional loyalties are often also existential lifelines that provide jobs, patronage and protection. In a self-regulating "profession" that seeks to maintain the right of self-regulation, this is a fatal flaw that can only lead to charges of uselessness and redundancy against which it is then impossible to defend the profession. All this sets up a vicious circle, where the purpose and meaning of writing and researching history, and its public purposes and meanings, are up for grabs in a situation of increasing murkiness and indecision.

Much of these reflections hinge on how political agendas are set or subverted within or outside the realms of academia, what the profession now considers "good practice" (which varies greatly, given that "historians" are now far from being a unified professional creed), how public uses of history set or curtail academic or political agendas, and the now-ubiquitous question of the identity, and therefore the qualification to make public utterances of the historian (who must be situated in, but often is reduced to, her "identity"). And if what might have been a series of admonitions to one's own profession has become relevant in a context where "fact" and "post-fact" have merged into a world in which we cannot recognise deliberate lies any more (we had long been sceptical of "truth"-claims, but we seemed to know a deliberate lie when we saw one), perhaps it is important for us as "professionals" to avoid condescension when faced with the history reading or history consuming public: to take them into confidence as to how the discipline functions, its crises and hesitations included. It 
is important that the process of history writing as much as its results are communicable.

This is not to suggest that a "public", however defined, should be empowered to set a research agenda for historians, or else we will have an alleged "nation" or "community" demanding that we treat nicely the Maratha King Shivaji, a historical figure appropriated to mythology, or promote the monkey god Hanuman, a mythological figure, to historical materiality, to the puzzlement of a less insular public that might otherwise be interested in histories of India. Nevertheless, a model that imagines a self-satisfied and self-regulating community of professionals versus a less-educated set of outsiders is vulnerable on a number of counts: at least of relevance (historians have not been particularly good at talking to one another at any level of coherence, so why should they exist at all?) and of mystification (if we cannot communicate, no one needs to make an effort to listen). The current model of interface with a public is for historians to self-censor to some extent, and for a "public" comprising right-wing paramilitary gangs or self-righteous Dalit groups to take offense at something a historian allegedly wrote (which they did not read but they knew they were offended by, or would have been had they read it). The question of the role that a "public" can or ought to have and that of the autonomy and self-regulation of the "profession" needs to be honestly and somewhat brutally discussed.

Parts of the material that have made their way into this book were written over a period of time when it was important to engage with and impossible to avoid the themes of identity and self-representation, and although all of the material has been rewritten to a greater or lesser extent, I have resisted the temptation to completely clean up the original essays to represent a position nearer to what I now hold. Written in the context of engagements with historical scholarship in/and public political debates in various parts of the world in which I have lived and/or worked (principally India, Britain and Germany in the 1990s, 2000s and 2010s, more or less in that order with some overlaps), each essay bears the traces of those interventions: context, as intellectual historians have always told us, is the key to understanding the nature of an intervention. Over time, the connected nature of the pieces became evident to me, and built up into an urge to gather them together and to make the connections explicit.

The book starts with my discomfort with postcolonial theories in and as history. Following that are essays that examine the state of the discipline, the art of reading and using archives, and practices of tracking the history of ideas, which I see as important to the continuance of a professional discipline of history. In-between are a number of pieces that play with themes of history, memory and identity in a variety of ways that PoMo might have called playful and ironic; I am happy to appropriate this description now, though in some cases I cannot recall 
the mood of the original. These in-between essays also enable a reading of the extent to which PoCo and PoMo were and are a part of my own writing. Contextualising authors is what historians were taught to do; often, it is all they do, as the (il)legitimacy of the voice amplifies or erases the argument that is made in and by that voice. It was a while ago that Roland Barthes informed us of the death of the author, at whose expense, he said, the reader was born; however, "the reader is without history". "This is an auspicious and facetious starting point; and I hope an actual death of the author might lead to a resurrection of the argument. Meanwhile, on the subject of trying to read the author, whose alleged death is often strategically overlooked, I cannot avoid being awarded or subtracted victimhood points in terms of my identity: sexual orientation, gender, bodily attributes, colour or hair; in previous publications I have provided some of the necessary autobiographical material for ad hominem arguments to be made. A quick, last word on the title: "the Last Post" might well mean "the most recent post”. I cannot predict endings, even as I am not against closure.

1 Roland Barthes, “The Death of the Author”, in Image-Music-Text, translated by Stephen Heath (London: Fontana, 1977), 142-148, quote from 148. 